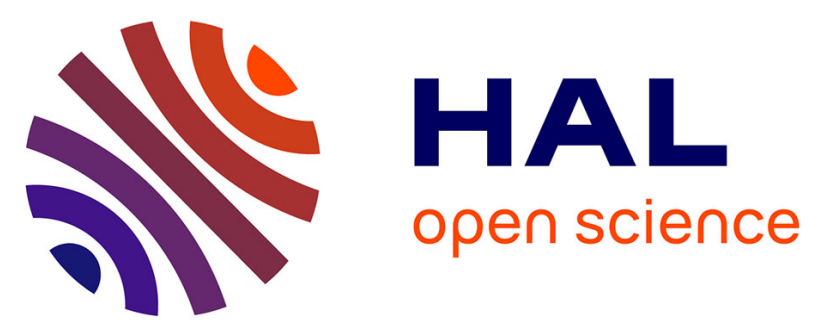

\title{
Whey protein isolate modulates beta-carotene bioaccessibility depending on gastro-intestinal digestion conditions
}

\author{
Mohammed Iddir, Celal Degerli, Giulia Dingeo, Charles Desmarchelier, \\ Thomas Schleeh, Patrick Borel, Yvan Larondelle, Torsten Bohn
}

\section{To cite this version:}

Mohammed Iddir, Celal Degerli, Giulia Dingeo, Charles Desmarchelier, Thomas Schleeh, et al.. Whey protein isolate modulates beta-carotene bioaccessibility depending on gastro-intestinal digestion conditions. Food Chemistry, 2019, 291, pp.157-166. 10.1016/j.foodchem.2019.04.003 . hal-02487079

\section{HAL Id: hal-02487079 \\ https://hal-amu.archives-ouvertes.fr/hal-02487079}

Submitted on 25 May 2020

HAL is a multi-disciplinary open access archive for the deposit and dissemination of scientific research documents, whether they are published or not. The documents may come from teaching and research institutions in France or abroad, or from public or private research centers.
L'archive ouverte pluridisciplinaire HAL, est destinée au dépôt et à la diffusion de documents scientifiques de niveau recherche, publiés ou non, émanant des établissements d'enseignement et de recherche français ou étrangers, des laboratoires publics ou privés. 


\section{Accepted Manuscript}

Whey protein isolate modulates beta-carotene bioaccessibility depending on gastro-intestinal digestion conditions

Mohammed Iddir, Celal Degerli, Giulia Dingeo, Charles Desmarchelier, Thomas Schleeh, Patrick Borel, Yvan Larondelle, Torsten Bohn

PII: S0308-8146(19)30651-X

DOI: https://doi.org/10.1016/j.foodchem.2019.04.003

Reference:

FOCH 24602

To appear in:

Food Chemistry

Received Date:

25 May 2018

Revised Date: 25 March 2019

Accepted Date:

1 April 2019

Please cite this article as: Iddir, M., Degerli, C., Dingeo, G., Desmarchelier, C., Schleeh, T., Borel, P., Larondelle, Y., Bohn, T., Whey protein isolate modulates beta-carotene bioaccessibility depending on gastro-intestinal digestion conditions, Food Chemistry (2019), doi: https://doi.org/10.1016/j.foodchem.2019.04.003

This is a PDF file of an unedited manuscript that has been accepted for publication. As a service to our customers we are providing this early version of the manuscript. The manuscript will undergo copyediting, typesetting, and review of the resulting proof before it is published in its final form. Please note that during the production process errors may be discovered which could affect the content, and all legal disclaimers that apply to the journal pertain. 
Whey protein isolate modulates beta-carotene bioaccessibility depending on gastro-intestinal digestion conditions

Mohammed Iddir ${ }^{1}$, Celal Degerli ${ }^{1,2}$, Giulia Dingeo ${ }^{1}$, Charles Desmarchelier ${ }^{3}$, Thomas Schleeh ${ }^{4}$, Patrick Borel $^{3}$, Yvan Larondelle ${ }^{5}$, Torsten Bohn ${ }^{1 *}$

${ }^{1}$ Luxembourg Institute of Health, Department of Population Health, Strassen, Luxembourg ${ }^{2}$ Ege University, Engineering Faculty, Food Engineering Department, Izmir, Turkey

${ }^{3}$ C2VN, INRA, INSERM, Aix-Marseille Univ, Marseille, France

${ }^{4}$ Luxembourg Institute of Science and Technology, Belvaux, Luxembourg

${ }^{5}$ University Louvain-la-Neuve, Institute of Life Sciences, Louvain-la-Neuve, Belgium

*To whom correspondence should be addressed:

Torsten Bohn

Luxembourg Institute of Health

$1 \mathrm{~A}-\mathrm{B}$, rue Thomas Edison

L-1445 Strassen, Luxembourg

E-mail: torsten.bohn@gmx.ch

Phone: +621-216-637

Running title: Whey proteins and $\beta$-carotene bioaccessibility 


\begin{abstract}
Carotenoids are lipophilic phytochemicals; their intake has been associated with reduced chronic diseases. However, their absorption depends on emulsification during digestion and incorporation into mixed micelles, requiring digestive enzymes, gastric peristalsis, bile, and dietary lipids. In this study, we investigated whether whey-protein-isolate (WPI), a commonly consumed protein source, can modulate $\beta$-carotene bioaccessibility in vitro, especially under incomplete digestive conditions, i.e. under low digestive enzyme conditions. Thus, pepsin and pancreatin, kinetic energy, gastric digestion time, and amount bile and co-digested lipids were modified, and WPI at concentrations equivalent to $0 / 25 / 50 \%$ of the protein recommended dietary allowance (approx. $60 \mathrm{~g} / \mathrm{d}$ ) were added to $\beta$-carotene dissolved in oil. WPI enhanced bioaccessibility by up to $20 \%(p<0.001)$, especially under higher simulated peristalsis or reduced dietary lipids. Conversely, they impaired bioaccessibility to one third $(p<0.001)$ under incomplete digestive conditions. WPI modulated $\beta$ carotene bioaccessibility depending on digestive conditions.
\end{abstract}

Key-words: Proteins, carotenoids, micellization, emulsion, digestion, lipid droplets, peristalsis. 


\section{Introduction}

Carotenoids and their metabolites are recognized as playing a role in the prevention of human diseases. Based on epidemiological studies, a positive association has been suggested between dietary intake and tissue concentrations of carotenoids and lowered risk of several chronic diseases (Elliott, 2005), such as cardiovascular diseases and type 2 diabetes (Sluijs, Cadier, Beulens, van der A, Spijkerman, \& van der Schouw, 2015), cancer (Sharoni, Linnewiel-Hermoni, Khanin, Salman, Veprik, Danilenko, et al., 2011), as well as reduced risk of age-related macular degeneration (Arunkumar, Calvo, Conrady, \& Bernstein, 2018). These correlations may be attributed to their antioxidant and anti-inflammatory activity (Krinsky, 2001), as well as their influence on the immune system (Rao \& Rao, 2007), both possibly related to a number of transcription factors and

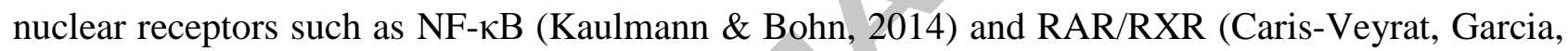
Reynaud, Lucas, Aydemir, \& Rühl, 2017). In addition to these health relevant aspects, certain carotenoids, including $\beta$-carotene, constitute vitamin A active compounds, following their cleavage by $\beta$-carotene oxygenase 1 (BCO-1) in vivo and metabolism into retinal.

Before being absorbed, carotenoids must be released from the food matrix and dissolved in lipid droplets. Then, under the influence of digestive enzymes (especially lipase), $\mathrm{pH}$, gastric peristalsis, and bile, carotenoids are incorporated into mixed micelles, allowing their uptake by the mucosa of the small intestine (Bohn, Desmarchelier, Dragsted, Nielsen, Stahl, Rühl, et al., 2017). Due to their lipophilic nature, the bioavailability of carotenoids, including $\beta$-carotene, is relatively low, typically between 10 and 20\% (Bohn, 2008; Desmarchelier \& Borel, 2017). Consequently, several studies have been investigating potential dietary as well as host-related factors influencing carotenoid bioavailability aspects, including their bioaccessibility and absorptive processes.

Regarding matrix-related factors, several studies have concluded that dietary lipids can significantly enhance carotenoid absorption, fostering micellization (Bohn, 2008; Huo, Ferruzzi, Schwartz, \& Failla, 2007). Also, it has been reported that dietary fiber can decrease the 
micellization of carotenoids, possibly by limiting enzymatic access and activity (O'Connell, Ryan, O'Sullivan, Aherne-Bruce, \& O'Brien, 2008). Recently, divalent minerals at higher concentrations were suggested to compromise carotenoid bioaccessibility, likely by precipitating fatty acids and bile salts (Biehler, Hoffmann, Krause, \& Bohn, 2011; Borel, Desmarchelier, Dumont, Halimi, Lairon, Page, et al., 2016). In addition to these dietary factors, it was shown that host-related factors can modulate carotenoid bioavailability (reviewed in Bohn, et al., 2017), including conditions that alter the gastro-intestinal (GI) surface area or digestive enzyme secretion. For example, bariatric surgery has been associated with several physiological modifications, among them, gastric peristalsis movement, at least in part explaining the decrease of plasma carotenoid concentrations (Granado-Lorencio, Simal-Anton, Blanco-Navarro, Gonzalez-Dominguez, \& Perez-Sacristan, 2011). In another study, it was reported that Crohn's disease resulted in carotenoid malabsorption (Edes, Walk, Thornton, \& Fritsche, 1991). Other anomalies such as cholecystectomy (reducing the available amount of bile), and pancreatitis (leading to secretory insufficiency of digestive enzymes) have been proposed to compromise carotenoid bioavailability (Desmarchelier \& Borel, 2017).

One factor that may impinge on carotenoid absorption, but has not yet received much attention, is the presence of proteins. For example, caseins have been successfully employed for micro- and nano-encapsulation of $\beta$-carotene, significantly improving its bioaccessibility (Soukoulis \& Bohn, 2018; Yi, Li, Zhong, \& Yokoyama, 2014). It was proclaimed that proteins may aid in the bioaccessibility of liposoluble dietary constituents in several ways. Following their adsorption to lipid droplet surfaces, proteins may stabilize oil-in-water $(\mathrm{o} / \mathrm{w})$ emulsions in the GI tract, attributed to the fact that proteins can be highly surface-active molecules (Mun, Kim, McClements, Kim, \& Choi, 2017; Soukoulis \& Bohn, 2018), and the formed particles tend to be highly negatively charged, preventing the aggregation of lipid droplets (Qiu, Zhao, Decker, \& McClements, 2015). However, the same study also showed that gliadin decreased the enzymatic degradation of lipids, likely by hindering digestive enzymes to adsorb to the droplet surfaces or binding to enzymes 
directly, also implying potential negative influences of proteins on the micellization process. Whey protein isolate (WPI) in contrast was effective at inhibiting lipid oxidation of o/w emulsions (Qiu, Zhao, Decker, \& McClements, 2015), which may contribute to limit oxidative degradation of sensitive molecules, as were caseino-phosphopeptides, which were proposed to chelate iron which may trigger oxidative degradation (Kim, Jang, \& Kim, 2007). Furthermore, WPI also facilitated the formation of smaller lipid droplets; Salvia-Trujillo and co-workers showed that reducing the diameter of these particles was related to increased $\beta$-carotene bioaccessibility (Salvia-Trujillo, Qian, Martin-Belloso, \& McClements, 2013).

It is assumed that the emulsifying properties are greatly influenced by the composition and structure of proteins. For instance, both hydrophobic and hydrophilic groups are abundant in WPI, highlighting its amphiphilic behavior (Sharif, Williams, Sharif, Abbas, Majeed, Masamba, et al., 2017). The structure of WPI is comprised of two main fractions, i.e. $\alpha$-lactalbumin (123 amino acids) and $\beta$-lactoglobulin (162 amino acids), together accounting for approx. $75 \%$ of the whey proteins, and their conformation (predominantly $\alpha$-helix and $\beta$-pleated sheet, respectively) affect their properties at the oil/water interface (Chatterton, Smithers, Roupas, \& Brodkorb, 2006).

In the current study, we aimed to investigate the effect of a commonly consumed protein source, WPI, on the bioaccessibility of pure $\beta$-carotene, under a range of digestive conditions, as proteins were hypothesized to rather enhance bioaccessibility under marginal, i.e. somewhat insufficient digestive conditions. For this purpose, we employed a previously established in vitro GI consensus model (Minekus, Alminger, Alvito, Ballance, Bohn, Bourlieu, et al., 2014), and WPI was added at different concentrations, reflecting various fractions of the recommended dietary allowance (RDA) of proteins, i.e. 0,25 and $50 \%$. Micellization of co-digested $\beta$-carotene thus measured also under insufficient digestion parameters (i.e. shortened gastric digestion duration, limited concentrations of digestive enzymes, gastric peristalsis, bile, and a surplus of dietary lipids), such as possible in subjects with GI disorders. 


\section{Materials and Methods}

\subsection{Enzymes and chemicals}

Pepsin from porcine gastric mucosa (powder, $\geq 250 \mathrm{U} / \mathrm{mg}$, Art. No. P7000), pancreatin from porcine pancreas (activity equivalent to 4x USP specifications. Art. No. P1750), porcine bile extract (Art. No. B8631), as well as $\beta$-carotene standard ( $\geq 97 \%$ UV, $>95 \%$ all-trans form according to supplier and own HPLC analysis, Art. No. 22040) were purchased from Sigma-Aldrich (Overijse, Belgium). Whey protein isolate (WPI) was obtained from Pure Nutrition USA (95\% purity, California, USA) while the peanut oil, typically free of native carotenoids (according to the USDA database and own blank examinations), was purchased from a local supermarket (Delhaize, Strassen) and used without further purification.

Unless otherwise specified, all chemicals were of analytical grade or superior. Potassium chloride ( $\geq 99 \%$, Art. No. P9541), potassium phosphate (monobasic $\geq 99$, Art. No. P5655), sodium bicarbonate ( $\geq 99$, Art. No. S5761), sodium chloride ( $\geq 99.5 \%$, Art. No. 71376), magnesium chloride hexahydrate (Art. No. M2393), ammonium carbonate (Art. No. 68392), sodium hydroxide solution (1 M, Art. No.1.09137), calcium chloride dihydrate ( $\geq 99$, Art. No. C3306), nile red (Art. No. 19123), fluorescein isothiocyanate isomer I (FITC) (Art. No. F7250), and phenolphthalein (Art. No. 105945) were acquired from Sigma-Aldrich. Hexane ( $\geq 95 \%$, Art. No. 24574), acetone ( $\geq 99 \%$, Art. No. 20063), and hydrochloric acid (1 M, Art. No. 30024.290) were obtained from VWR (Leuven, Belgium).

\section{2 $\beta$-Carotene, WPI and enzyme solutions}

$\beta$-Carotene standard solution was first prepared by dissolving $1 \mathrm{mg}$ of $\beta$-carotene standard in 2 $\mathrm{mL}$ of hexane. The solution was sonicated for $5 \mathrm{~min}$. and warmed up at $30^{\circ} \mathrm{C}$ for $5 \mathrm{~min}$. (Ultrasonic Cleaner, VWR Symphony ${ }^{\circledR}$, Massachusetts, USA). Then, $1 \mathrm{~mL}$ of peanut oil was added to foster the 
dissolution of $\beta$-carotene by sonication and warming at $30{ }^{\circ} \mathrm{C}$ for $5 \mathrm{~min}$. The hexane was removed by evaporation under a stream of nitrogen for $\pm 20 \mathrm{~min}$. at $30{ }^{\circ} \mathrm{C}$ (TurboVap LV from Biotage ${ }^{\circledR}$, Uppsala, Sweden). The standard $\beta$-carotene solution was made by the addition of $4 \mathrm{~mL}$ of peanut oil to the remaining $1 \mathrm{~mL}$ to reach a concentration of $0.2 \mathrm{mg} / \mathrm{mL}$, and two other concentrations $(0.1$ and $0.4 \mathrm{mg} / \mathrm{mL}$ ) were also prepared for further investigation by adding 9 and $1.5 \mathrm{~mL}$ (instead of 4 $\mathrm{mL}$ ) of peanut oil, respectively. The concentration of the standard solutions was later verified spectrophotometrically as explained below (section 2.5). Aliquots of the standard solutions were pipetted into $15 \mathrm{~mL}$ falcon tubes, and stored at $-80{ }^{\circ} \mathrm{C}$ until usage.

Assuming a total volume of $2 \mathrm{~L}$ of intestinal fluids during GI digestion, the amount of $\beta$-carotene added to each digesta was $30 \mu \mathrm{g}$, by pipetting 75,150 or $300 \mu \mathrm{L}$ from the standard solutions $(0.4$, 0.2 or $0.1 \mathrm{mg} / \mathrm{mL}$, respectively), representing $1.2 \mathrm{mg} / \mathrm{L}$ of $\beta$-carotene and 3,6 or $12 \mathrm{~g} / \mathrm{L}$ of oil (Table 1).

In the same way, the amounts of WPI tested were $0,7.5$ and $15 \mathrm{~g} / \mathrm{L}$ (Table 1), corresponding to 0 , 25 and $50 \%$ of the recommended dietary allowance (RDA) (60 g/d for human adults) (Hautvast, Baya, Amorim Cruz, de Backer, Ducimetiere, Durnin, et al., 1989). Practically, 0, 187.5 or 375 mg of WPI were dissolved in $6.25 \mathrm{~mL}$ of pure water, and together with the added $\beta$-carotene solution in oil, the final ratio of matrix (WPI+ $\beta$-carotene solution) to simulated gastric fluid of 50:50 (v/v) was reached. A brief mixing of the WPI solution with the beta-carotene in peanut oil and the simulated gastric fluid (SGF) was achieved by vortexing for $15 \mathrm{sec}$.

SGF and the simulated intestinal fluid (SIF) were made as recommended by the European consensus digestion model (Minekus, et al., 2014). Pepsin solution was prepared in SGF to reach a final concentration of $2000 \mathrm{U} / \mathrm{mL}$ of the final gastric mixture. In addition to the standardized concentration (Table 1), two other concentrations were tested (1000 and $4000 \mathrm{U} / \mathrm{mL}$ ). 
Regarding pancreatin and bile extract, pancreatin was weighed based on a trypsin activity of 100, 200 or $400 \mathrm{U} / \mathrm{mL}$, while the bile extract was weighed in order to reach a concentration of 3.4, 6.8 or $13.6 \mathrm{mg} / \mathrm{mL}$ of the final digestion volume (Table 1); both were prepared in the same SIF solution.

It is noteworthy that the European consensus suggested a standardized amount of pancreatin based on trypsin activity at $100 \mathrm{U} / \mathrm{mL}$, but in the present study, pancreatin amount was doubled following pre-experiments ( $200 \mathrm{U} / \mathrm{mL}$ of trypsin), in order to enhance the digestibility of both WPI and oil (by increasing at the same time the lipase activity). As explained above, two other concentrations of pancreatin $(100$ and $400 \mathrm{U} / \mathrm{mL})$ as well as bile extract $(3.4$ and $13.6 \mathrm{mg} / \mathrm{mL})$ were tested. Conditions with low pancreatin $(100 \mathrm{U} / \mathrm{mL})$ and/or low bile $(3.4 \mathrm{mg} / \mathrm{mL})$ are denoted in the following as marginal digestive conditions in this investigation.

\subsection{Simulation of gastro-intestinal (GI) digestion}

In vitro simulated GI digestion was carried out according to the harmonized INFOGEST protocol, with some modifications as explained above (section 2.2). The model was used to test the influence of proteins at three different concentrations on $\beta$-carotene bioaccessibility, including also rather marginal, i.e. insufficient digestion parameters. The oral phase was omitted as the matrix employed did not include significant amounts of carbohydrates and was liquid.

For the gastric phase, $6.25 \mathrm{~mL}$ of protein solution at the desired concentration (equivalent to 0,25 or $50 \%$ of the RDA) was added to each sample, followed by the addition of 75,150 or $300 \mu \mathrm{L}$ of $\beta$ carotene solution in oil (corresponding to a total of $30 \mu \mathrm{g}$ of $\beta$-carotene per digest, with amounts similar to former in vitro experiments (Biehler et al. 2011)). Before the addition of $4 \mathrm{~mL}$ of SGF (1.25 x concentrate), $1 \mathrm{~mL}$ of pepsin solution was added to the mixture in order to reach enzymatic activities of $1000,2000,4000 \mathrm{U} / \mathrm{mL}$ of the final gastric volume. Then, $31 \mu \mathrm{L}$ of calcium dichloride $(0.03 \mathrm{M})$ was added to reach a concentration of $0.075 \mathrm{mM}$ in the final mixture, and finally, $\mathrm{pH}$ 
adjustment to 3 by hydrochloric acid $(1 \mathrm{M})$ was carried out, bringing the volume of each sample to $12.5 \mathrm{~mL}$ with pure water.

Finally, the samples were incubated in a shaking water bath (GFL 1083 from VEL ${ }^{\circledR}$, Leuven, Belgium) for 1 or $2 \mathrm{~h}$ at $37{ }^{\circ} \mathrm{C}$, with a shaking speed of 75 or 100 rounds per minute (equal to a doubling of the kinetic energy, which is proportional to the square of the speed), depending on the desired condition. In the standardized INFOGEST digestion model (Minekus, et al., 2014), no specific shaking speed was suggested.

At the end of the gastric incubation, $7.5 \mathrm{~mL}$ of SIF, and $2.5 \mathrm{~mL}$ of pancreatin and bile extract solution at various concentrations $(100,200$ or $400 \mathrm{U} / \mathrm{mL}$ based on trypsin activity for pancreatin, and $3.4,6.8$ or $13.6 \mathrm{mg} / \mathrm{mL}$ for the bile extract) were added to the chyme. Then, $250 \mu \mathrm{L}$ of calcium dichloride $(0.03 \mathrm{M})$ was added to reach a concentration of $0.3 \mathrm{mM}$ in the final mixture. Before bringing the volume to $25 \mathrm{~mL}$, the $\mathrm{pH}$ was adjusted to 7 by the addition of sodium hydroxide solution $(1 \mathrm{M})$, then the samples were incubated for $2 \mathrm{~h}$ at $37^{\circ} \mathrm{C}$, with a shaking speed of 75 or 100 rounds per minute (rpm).

\section{4 $\beta$-Carotene extraction}

At the end of the intestinal incubation, $12 \mathrm{~mL}$ were removed from the digesta and transferred into $15 \mathrm{~mL}$ falcon tubes. The samples were centrifuged for $1 \mathrm{~h}$ at $3200 \mathrm{xg}\left(4^{\circ} \mathrm{C}\right)$, then $5 \mathrm{~mL}$ were collected from the middle aqueous phase and filtered through $0.2 \mu \mathrm{m}$ nylon membrane syringe filter. In a new $15 \mathrm{~mL}$ falcon tube, $4 \mathrm{~mL}$ of hexane:acetone $(2: 1, \mathrm{v}: \mathrm{v})$ were added to $2 \mathrm{~mL}$ of the filtered aqueous phase, vortexed for $30 \mathrm{sec}$. and centrifuged for $2 \mathrm{~min}$. at $3200 \mathrm{x} \mathrm{g}\left(4^{\circ} \mathrm{C}\right)$. The supernatant, which represents the hexane phase, was transferred into a new falcon tube, then the extraction process was repeated two times with $4 \mathrm{~mL}$ of hexane. All extracts were combined in the same tube and dried under a stream of nitrogen and stored at $-80{ }^{\circ} \mathrm{C}$ until analysis. 


\subsection{Spectrophotometric analysis}

Spectrophotometric analysis of $\beta$-carotene was done as described previously (Corte-Real, Richling, Hoffmann, \& Bohn, 2014). The dried residue was reconstituted in $1 \mathrm{~mL}$ of cold $\left(4^{\circ} \mathrm{C}\right)$ hexane and transferred to a $1 \mathrm{~mL}$ quartz cuvette (absorption cuvette, Hellma ${ }^{\circledR}$, New York, USA). The absorbance was measured between 300 and $600 \mathrm{~nm} \quad\left(\right.$ GENESYS $^{\mathrm{TM}} 10 \mathrm{~S}$ UV-Vis Spectrophotometer, Thermo Fisher Scientific, Massachusetts, USA). The concentration was calculated by applying the Beer-Lambert law, taking into account the molar absorption coefficient (Britton, Liaaen-Jensen, \& Pfander, 2004), and different dilution steps:

$$
C=\frac{a b s_{450} * F d}{\varepsilon_{\lambda}} x d \times M
$$

where $C=$ concentration of the measured solution $(\mathrm{mg} / \mathrm{mL}), a b s_{\max }=$ maximum measured absorbance of $\beta$-carotene at approx. $450 \mathrm{~nm}, F \mathrm{~d}=$ dilution factor adjusting for extraction or reconstitution process, $\varepsilon_{\lambda}=$ molar absorption coefficient $\left(\mathrm{Lmol}^{-1} \mathrm{~cm}^{-1}\right)$ of $\beta$-carotene in hexane (138824), $d=$ length of light pathway through cuvette $(\mathrm{cm})$ and $\mathrm{M}=\beta$-carotene molar mass $(536.89 \mathrm{~g} / \mathrm{mol})$.

Finally, the percentage of $\beta$-carotene micellization was used as a measure of bioaccessibility, and was expressed as the percentage of the solubilized amount of $\beta$-carotene present in the aqueous phase of the filtered digesta after in vitro GI digestion, compared to the initial amount added to the sample.

\subsection{Further physico-chemical characterization of digesta}

To study further physico-chemical properties of the digesta, macroviscosity and surface tension, micelle size and zeta potential, fatty acid titration, and the emulsion structures were investigated, as these parameters were also believed to possibly impinge on $\beta$-carotene bioaccessibility.

2.6.1 Rheological measurements and surface tension of the digesta 
Flow curves were determined as a function of the shear rate between $0.1 \mathrm{~s}^{-1}$ and $130 \mathrm{~s}^{-1}$ on an Anton-Paar rheometer (MCR 302, WESP, Graz, Austria), equipped with a double gap cell at $5^{\circ} \mathrm{C}$. Each measurement cycle did comprise a temperature equilibration phase, a pre-shear phase at $5 \mathrm{~s}^{-1}$ of $60 \mathrm{~s}$, a flow curve with increasing shear rates, an intermediate equilibration phase at $131 \mathrm{~s}^{-1}$ of 60 $\mathrm{s}$ and a flow curve with decreasing shear rates. At the end of each cycle, a regression flow curves was calculated for the shear rate range between $0 \mathrm{~s}^{-1}$ and $100 \mathrm{~s}^{-1}$ for the shear stress respectively between $1 \mathrm{~s}^{-1}$ and $100 \mathrm{~s}^{-1}$ for the viscosity. Each measurement cycle was performed three times, because of the fluidity of the samples. The regression curves were averaged and plotted as viscosity and shear stress as a function of the shear rate.

Surface tension of digesta samples, pre-conditioned at $25 \pm 0.1{ }^{\circ} \mathrm{C}$, were determined by the weight-drop method as previously described by (Permprasert \& Devahastin, 2005). The air-water interfacial properties of digesta were calculated as follows:

$$
\sigma_{\text {digesta }}=\frac{m_{\text {digesta }}}{m_{\mathrm{H} 2 \mathrm{O}}} \times \sigma \mathrm{H}_{2} \mathrm{O}
$$

where $\sigma_{\mathrm{H} 2 \mathrm{O}}=71.99 \mathrm{dyn}^{-1}$ is the surface tension of pure water.

\subsubsection{Micelle size and zeta potential analysis}

Aliquots of the aqueous micellar fraction obtained after GI digestion under standard conditions (Table 1) were filtered through a $0.2 \mu \mathrm{m}$ nylon membrane syringe filter for the analysis of the micelle size and zeta potential. The intensity-weighted mean hydrodynamic radius and zeta potential were determined by dynamic light scattering and laser doppler micro-electrophoresis, respectively. Measurements were done at room temperature with at least four replicates, by using a Zetasizer Nano Zs instrument (Malvern Instruments, Malvern, UK).

\subsubsection{Lipid and protein digestion}


The amount of free fatty acids in the digesta after GI digestion was estimated as described previously (Corte-Real, Desmarchelier, Borel, Richling, Hoffmann, \& Bohn, 2018), based on the titration against sodium hydroxide $(\mathrm{NaOH} 0.1 \mathrm{M})$, using phenolphthalein as an indicator.

Sodium dodecyl sulfate-polyacrylamide gel-electrophoresis (SDS-PAGE) was carried out to study completeness of protein digestion. Samples were denatured at $95^{\circ} \mathrm{C}$ for $5 \mathrm{~min}$. in Lämmli buffer. About $22 \mu \mathrm{g}$ of protein per pocket was loaded to a $15 \%$ acrylamide and $0.4 \%$ bisacrylamide gel (gastro-intestinal digestion) and $45 \mu \mathrm{g}$ of protein per pocket was loaded to a $10 \%$ acrylamide/ $0.3 \%$ bisacrylamide gel (gastric digestion). Marker was Invitrogen novex see blue plus 2 (Invitrogen, Carlsbad, CA). Gel was run at $80 \mathrm{~V}$ (30 min.) plus $100 \mathrm{~V}$ (90 min.). Running buffer contained SDS (0.1\%), glycine $(190 \mathrm{mM})$, tris- $\mathrm{HCl}(25 \mathrm{mM})$. Fixation/staining was done with methanol/acetic acid/coomassie brilliant blue $\mathrm{R}(50 \%, 10 \%, 0.1 \%)$ (30 minutes), destaining in methanol/glacial acetic acid/water $(30 \%, 10 \%, 60 \%, 3$ h). Pictures were taken in a Kodak Gel Logic 2200 Imaging System (Kodak, Rochester, NY).

\subsubsection{Confocal laser scanning microscopy (CLSM)}

Confocal imaging of emulsion structures before and after GI digestion under standard conditions (Table 1) was carried out at room temperature with a confocal laser scanning microscope (Zeiss LSM 880, Airyscam SR, Jena, Germany), using a 63x objective. Nile Red dissolved in ethanol and FITC dissolved in acetone were mixed into the aliquots of digesta for fat and protein staining with final concentrations in the samples of $1 \mu \mathrm{g} / \mathrm{mL}$. A small-sample aliquot was placed on a slide for visualization. The fluorescent dyes were excited by an Argon $488 \mathrm{~nm}$ laser and the emitted light was collected at $522 \mathrm{~nm}$ for proteins and $635 \mathrm{~nm}$ for the fat phase. The diameter of lipid droplets ( $n=20$ /group) at various concentration of WPI was measured by using a modular image-processing and analysis software for digital microscop (Zen 2.3 blue edition, Carl Zeiss Microscopy GmbH, Jena, Germany). 


\subsection{Statistical analyses and data treatment}

In order to minimize day-to-day variations between experiments, bioaccessibility of $\beta$-carotene was normalized to a daily control which was assessed for each digestion. Unless otherwise stated, all values are expressed as the mean \pm standard deviation. Replicates were obtained from at least 2 individual sets of analyses obtained at different days $(\mathrm{N} \geq 2)$, and at least 4 replicates were obtained for each digestive condition during 1 set of analyses.

Statistical analysis was performed using SPSS 22 software (SPSS Inc., Chicago, IL). Normal distribution of data was verified by Q-Q -plots and equality of variance by box-plots and Levene's test. For statistical evaluation, $\beta$-carotene bioaccessibility values were log-transformed to achieve a normal distribution. Linear mixed models were developed with the effect of WPI concentration, amount of lipid source, bile extract concentration, kinetic energy and duration of gastric phase, pepsin and pancreatin concentration as fixed factors and log- $\beta$-carotene bioaccessibility as the observed dependent factor. As a model including all factors was not fully factorial, but several significant interactions were obtained, additional linear mixed models were run to keep constant certain parameters and to better allow further group-wise comparisons. P-values $<0.05$ were considered statistically significant different (2-sided). Where needed, Fisher F-tests were followed by post hoc tests (Bonferroni, for comparing $>3$ groups) or LSD tests (for comparison of $\leq 3$ groups).

\section{Results}

3.1 Interactions of WPI with matrix related effects affecting $\beta$-carotene bioaccessibility

3.1.1 Bioaccessibility under standard conditions and with escalating concentrations of WPI

Under control conditions (no addition of WPI), bioaccessibility of pure $\beta$-carotene following the GI digestion averaged approx. $0.3 \mu \mathrm{g} / \mathrm{mL}$, representing around $25 \%$ of $\beta$-carotene recovered from 
the aqueous micellar fraction at the end of the in vitro digestion, compared to the initial amount added at the beginning of digestion (Fig. 1A). Although the addition of an equivalent of $50 \%$ protein RDA of WPI slightly enhanced bioaccessibility (Fig. 1A) compared to the control (no protein added), this effect was not significant under standard conditions (Minekus, et al., 2014).

\subsubsection{Influence of WPI at different amounts of co-digested oil on $\beta$-carotene bioaccessibility}

Following linear mixed models, the effect of oil $(p<0.001)$ was statistically significant, while the influence of WPI had no significant effect. In addition, a significant interaction between the amount of added oil and WPI concentration was encountered $(p<0.001)$, thus the effects were further studied at individual WPI levels.

When no WPI was added, increasing the volume of oil (up to $300 \mu \mathrm{L}$ ) negatively affected the bioaccessibility $(p<0.001)$ compared to the standard conditions $(150 \mu \mathrm{L}$ of oil). No significant effect on $\beta$-carotene bioaccessibility was observed with a lower amount of oil ( $75 \mu \mathrm{L}$ of oil, Fig. 1B, Table 2).The addition of $25 \%$ RDA of WPI to samples with a reduced amount of oil further enhanced the bioaccessibility (by up to 20\%) compared to the control, while the addition of WPI at 50\% RDA had no significant effect (Fig. 1B). However, adding WPI to the simulated GI digestion with a high volume of oil $(300 \mu \mathrm{L})$ caused an additional decrease in bioaccessibility, in a dose dependent manner $(p<0.001)$. In this scenario, adding the equivalent of 25 and $50 \%$ RDA of WPI significantly decreased $\beta$-carotene bioaccessibility by $20 \%(p=0.017)$ and up to $35 \%(p<0.001)$, respectively, compared to the control (no WPI).

\subsection{Influence of WPI on $\beta$-carotene bioaccessibility at various gastric conditions}

3.2.1 Impact of WPI at altered simulated peristalsis on $\beta$-carotene bioaccessibility

Following linear mixed models, the effect of peristalsis conditions on $\beta$-carotene bioaccessibility was statistically significant $(p<0.001)$, while the influence of WPI had no significant effect. Also, 
the interaction between the added amount of WPI and peristalsis movements had a significant ( $p=0.019$ ) effect on the bioaccessibility of $\beta$-carotene, thus effects were further studied at individual shaking speed.

The higher shaking water speed of $100 \mathrm{rpm}$ induced an up to two times higher $\beta$-carotene micellization $(p<0.001)$ compared to the lower speed of $75 \mathrm{rpm}$ (Fig. 2, Table 2), across all 3 levels of proteins present $(0,25$ or $50 \%$ of RDA), at $2 \mathrm{~h}$ of gastric digestion time.

Following all-group-wise comparisons (post hoc-tests), the addition of $25 \%$ RDA of WPI significantly increased $(p<0.001) \beta$-carotene bioaccessibility when a higher kinetic energy was applied, relative to the control (Fig. 2A). However, no significant influence was observed with the addition of 50\% RDA of WPI, i.e. WPI did not influence $\beta$-carotene bioaccessibility in a linear dose-dependent manner.

\subsubsection{Influence of WPI on $\beta$-carotene bioaccessibility at altered gastric phase duration}

Following linear mixed models, the effect of gastric phase duration $(p<0.001)$ was statistically significant, while the influence of WPI had no overall significant effect. However, the impact of gastric digestion time ( 2 ys. 1 h) depended significantly on the shaking speed $(p=0.0016$, Fig. $2 \mathrm{~A})$, with larger differences observed at lower simulated peristalsis.

Reducing gastric transition to $1 \mathrm{~h}$ decreased bioaccessibility by $25 \%$ at $75 \mathrm{rpm}$ (in general for all levels of WPI addition), while the negative effect was less pronounced, yet significant, with a higher shaking speed, compared to the standardized $2 \mathrm{~h}$ of gastric phase $(p<0.001$, Table 2$)$.

At $75 \mathrm{rpm}$, no further influence was noticed on $\beta$-carotene bioaccessibility following the addition of WPI, with a reduced gastric digestion time (Fig. 2A), while a significant $(p<0.001)$ interaction was found at $100 \mathrm{rpm}$ between protein concentration and gastric phase duration (Fig. 2A). Here, the addition of WPI significantly $(p<0.001)$, though only slightly, increased the bioaccessibility of $\beta$ carotene by up to $20 \%$ (for the $25 \%$ RDA protein group), compared to the control. 


\subsubsection{Effect of varying concentrations of pepsin}

Following linear mixed models, the effects of both WPI $(\mathrm{p}<0.001)$ and of pepsin concentration $(\mathrm{p}<0.001)$ were statistically significant. A statistical significant interaction of pepsin $\mathrm{x}$ protein $(p=0.008)$ was also found regarding $\beta$-carotene bioaccessibility.

Under control conditions (no WPI), no influence of varying the amount of pepsin on $\beta$-carotene micellization (Fig. 3A) was found. Similarly to the standard conditions (2000 U/mL of pepsin), addition of WPI to the simulated GI digestion with $4000 \mathrm{U} / \mathrm{mL}$ of pepsin did not influence $\beta$ carotene bioaccessibility compared to the daily control (Table 2). However, the addition of WPI to the samples with a lower concentration of pepsin decreased $\beta$-carotene bioaccessibility by up to $40 \%(p<0.001)$, compared to the control (no WPI).

\subsection{Influence of WPI at altered intestinal conditions}

\subsubsection{Effect of varying concentrations of bile extract}

Following linear mixed models, the effects of both WPI $(\mathrm{p}=0.002)$ and of bile concentration $(\mathrm{p}<0.001)$ were statistically significant. In addition, a significant interaction between added amounts of bile extract and protein concentration was found $(p<0.001)$.

A maximum of $\beta$-carotene micellization (around 25\%) was obtained with the higher amounts of bile extract $(6.8$ and $13.6 \mathrm{mg} / \mathrm{mL})$, while $3.4 \mathrm{mg} / \mathrm{mL}$ of bile extract significantly $(p<0.001)$ decreased $\beta$-carotene bioaccessibility, compared to the standard conditions ( $6.8 \mathrm{mg} / \mathrm{mL}$, Fig. 3B).

There was no significant effect of adding WPI at high amounts of bile $(6.8$ and $13.6 \mathrm{mg} / \mathrm{mL}$ per digesta), except for a slight decrease of $\beta$-carotene bioaccessibility when 50\% RDA of WPI was added to the samples with highest amounts of bile extract $(p=0.0011)$. However, the addition of WPI to the digesta with reduced amount of bile extract $(3.4 \mathrm{mg} / \mathrm{mL})$ negatively affected the bioaccessibility in a concentration dependent manner $(\mathrm{p}<0.001)$. The addition of $25 \%$ and $50 \%$ 
RDA of WPI decreased the bioaccessibility to half and $1 / 3$, respectively, compared to the control $(p<0.001$, Table 2).

\subsubsection{Effect of varying concentrations of pancreatin}

Following linear mixed models, the effects of both WPI amount $(p=0.009)$ and of pancreatic enzyme concentrations $(p<0.001)$ were statistically significant. Under control conditions (no WPI), increasing the pancreatin concentrations positively affected the bioaccessibility $(p<0.001)$ in a concentration dependent manner (Fig. 2B), i.e. increasing $\beta$-carotene micellization from $25 \%$ up to $34 \%(75 \mathrm{rpm})$, and from $45 \%$ up to $68 \%(100 \mathrm{rpm})$.

Furthermore, a statistical interaction (pancreatin $\mathrm{x}$ peristalsis $\mathrm{x}$ protein, $p=0.004$ ) regarding $\beta$ carotene bioaccessibility was also found. At $75 \mathrm{rpm}$, the addition of WPI to the simulated GI digestion with half the typical amount of pancreatin negatively affected $(p<0.001) \beta$-carotene bioaccessibility, by up to $50 \%$, compared to the control (Fig. 2B, Table 2), in a dose-dependent fashion. When doubling the amount of pancreatin to $400 \mathrm{U} / \mathrm{mL}$, a significant $(p<0.001)$ negative effect of WPI on $\beta$-carotene micellization was found only with the addition of $25 \%$ RDA, compared to the control.

A similar effect was observed for conditions resembling a stronger peristalsis effects (100 rpm). Using the double amount of pancreatin $(400 \mathrm{U} / \mathrm{mL})$ slightly decreased $\beta$-carotene micellization following the addition of 50\% RDA of WPI ( $p=0.006$, Fig. 4). However, employing half the amount of pancreatin compared to standard digestive conditions resulted in ambivalent effects, with $25 \%$ RDA of WPI resulting in enhanced $\beta$-carotene bioaccessibility $(p=0.004)$, while the addition of $50 \%$ RDA of WPI slightly decreased $\beta$-carotene bioaccessibility $(p=0.015)$, compared to the control.

3.4 Effect of WPI on the physico-chemical properties of the digesta 
In general, the shear stress and viscosity of digested samples at various concentrations of WPI was found very close to that of aqueous systems (Supplementary Fig. 1A, left panel), and samples had a very small yield point (0.01 Pa or even lower), with lower yield points after digestion. Nondigested WPI solutions at 0\% RDA and all digested solutions showed almost Newtonian behaviour above shear rates of $5 \mathrm{~s}^{-1}$ (Supplementary Fig. 1A, right panel).

Surface tension for control and supplemented digesta with $25 \%$ of WPI showed no significant difference (Supplementary Fig. 2). The addition of 50\% WPI slightly reduced surface tension compared to the control digesta $(p<0.001)$, being in line with the higher macroviscosity data.

Regarding mixed micelle size and zeta potential, both $25 \%$ and $50 \%$ RDA of WPI additions resulted in significantly reduced micelle size of $3.3 \pm 0.1 \mathrm{~nm}$ compared to WPI free control digesta (supplementary Fig. 3A, $p<0.001$ ). However, the average absolute zeta potential of the samples digested with $25 \%$ and $50 \%$ RDA of WPI was somewhat reduced (from $-46.8 \pm 1 \mathrm{mV}$ to $-25.3 \pm$ 6.2 and $-28.8 \pm 1.7 \mathrm{mV}$, respectively (Supplementary Fig. 3B, $p<0.001$ ).

Lipid digestion results obtained by fatty acid titration were not fully informative and rather reflected the buffering capacity of the added proteins, and/or additional protein hydrolysis, thus it was not feasible to separate their contribution to lipolysis (Supplementary Fig. 4). The size of lipid droplets and the co-location of lipids and proteins at $25 \%$ and $50 \%$ RDA samples were measured by confocal microscope. Prior to digestion, the lipid droplets were distributed as large aggregates of lipid droplets in the mixture. With increasing concentration of WPI, the lipid droplets formed smaller aggregates in the digesta (Fig. 4A). The higher concentration of WPI resulted in a smaller average lipid droplet size compared to the control digesta, decreasing from $13.42 \pm 9.28$ to $4.84 \pm$ 1.52 and to $3.35 \pm 1.76 \mu \mathrm{M}$ for 0,25 and $50 \%$ WPI, respectively (Supplementary table I), with the first group being significantly different from the last 2 groups $(p<0.001)$.

Regarding protein digestion, there was no detectable difference between the various digestive conditions on the WPI originating bands detectable by SDS-PAGE, following either gastric or 
gastro-intestinal digestion (Supplementary fig. 5, upper panel). Gastro-intestinal digestion suggested the complete digestion of WPI into smaller fragments during all digestive conditions, as no major bands were visible following digestion. Only bands originating from enzyme additions were detectable after gastro-intestinal digestion. Following only gastric digestion however (Supplementary fig. 5, lower panel), fragments around $18 \mathrm{kDa}$ were clearly visible after WPI digestion, for all digestive conditions, likely representing either $\alpha$-lactalbumin (14.2 kDa) and or $\beta$ lactoglobulin $(18.4 \mathrm{kDa})$.

\section{Discussion}

Micellization of $\beta$-carotene constitutes one of the major steps determining its absorption and bioavailability, and previous studies have shown that they are well correlated (Biehler \& Bohn, 2010; Reboul, Richelle, Perrot, Desmoulins-Malezet, Pirisi, \& Borel, 2006). Several reports have highlighted matrix-related as well as host-related factors influencing carotenoid bioaccessibility and absorptive process, as reviewed earlier (Bohn, 2008; Bohn, et al., 2017). In this regard, proteins have been proclaimed to aid in emulsifying liposoluble dietary constituents (Soukoulis \& Bohn, 2018), but their presence has also shown a negative influence on lipid degradation, which could have an impact on the micellization process (Qiu, Zhao, Decker, \& McClements, 2015). In the present study, we investigated the effect of WPI, a commonly consumed protein, on $\beta$-carotene bioaccessibility under selective simulated digestion conditions to study its influence at more physiological vs. somewhat sub-optimal conditions regarding lipid and protein digestion.

The most important finding was that the influence of WPI on $\beta$-carotene depended on digestive conditions. More specifically, WPI reduced $\beta$-carotene bioaccessibility by approx. $70 \%$ when lipid digestion was rather compromised by lower concentrations of bile, enzymes, or when reducing shaking speed. However, under certain conditions, enhanced bioaccessibility, compared to standard digestion conditions (European consensus model, (Minekus, et al., 2014)), of up to 20\%, were also 
encountered, but appeared less consistent. Under standard digestion conditions (Table 1, Fig. 1A), adding WPI reflecting 0,25 and $50 \%$ of the RDA for a $70 \mathrm{~kg}$ adult (assuming a digestion volume of 2 L) during simulated GI digestion, had no significant effect on the micellization of $\beta$-carotene, in spite of resulting in lower lipid droplet size after GI digestion. To our knowledge, this is the first report systematically investigating carotenoid bioaccessibility in the presence of a co-digested protein, under varying simulated digestion conditions.

Whey protein consists primarily of $\beta$-lactoglobulin (50-55\%) and $\alpha$-lactalbumin (20-25\%). Regarding its emulsion stabilizing capability, it was emphasized that the high percentage of $\beta$ pleated sheet $(\sim 50 \%)$ conformation and the relatively low content of the $\alpha$-helix form $(\sim 15 \%)$ allows $\beta$-lactoglobulin (due to its higher hydrophobicity) to adsorb and produce better conformational changes at the o/w interface, compared to $\alpha$-lactalbumin $(\beta$-sheet $\sim 9 \%, \alpha$-helix 45\%) (Carbonaro, Maselli, \& Nucara, 2012; Schröder, Berton-Carabin, Venema, \& Cornacchia, 2017). In addition, during the gastric phase, a complete hydrolysis of $\alpha$-lactalbumin was found, while a portion of $\beta$-lactoglobulin remained resistant after $1 \mathrm{~h}$ (Malaki Nik, Wright, \& Corredig, 2011). Thus, in whey protein-stabilized emulsions, $\beta$-lactoglobulin may play a greater role regarding emulsion stability, compared to $\alpha$-lactalbumin.

The strongest positive significant effects of WPI addition were observed when halving the amount of oil (Fig. 1B) and doubling the peristalsis energy (Fig. 2A), reflecting more efficient digestive conditions. The effects were an approx. 20\% increase, compared to their respective controls (no WPI addition), but only at protein concentrations equivalent to $25 \%$ RDA, not $50 \%$ RDA. It was reported earlier that $\beta$-lactoglobulin can interact with $\beta$-carotene within a pocket of hydrophobic residues, with strong non-covalent interactions (Mensi, Choiset, Rabesona, Haertle, Borel, \& Chobert, 2013), suggesting that WPI can act as a vehicle for hydrophobic compounds during the GI digestion. This may explain the positive effect observed when reducing the amount of oil. Such carotenoid-protein interactions are not an isolated case. For instance, orange carotenoid- 
protein complexes with glutathione-S-transferase and crustacyanin are examples of well characterized carotenoid-binding proteins (Pilbrow, Garama, \& Carne, 2012). In addition, native whey proteins are highly surface-active molecules (Mun, Kim, McClements, Kim, \& Choi, 2017). It was demonstrated that the proteins and peptides liberated during GI digestion can affect the stability of o/w emulsions (van der Ven, Gruppen, de Bont, \& Voragen, 2001), as well as retarding triglyceride oxidation (Qiu, Zhao, Decker, \& McClements, 2015). It was also reported that after gastric digestion, some of the protein fragments remained adsorbed to the lipid droplet surfaces. However, these appeared to be removed into the surrounding aqueous phase following further proteolysis by pepsin, the low $\mathrm{pH}$, and peristalsis movements in the stomach, as well as further action of the bile salts in the small intestine (Mun, Kim, McClements, Kim, \& Choi, 2017), allowing access to lipolytic enzymes. This is in line with results from the present study, as no more adsorption of proteins to lipid droplets in fully digested samples was seen by confocal microscopy. These considerations are in line with the present outcomes (Fig. 2A) and the positive influence of peristalsis movements on the bioaccessibility.

Contrarily, the higher dose of WPI (reflecting 50\% RDA) resulted in reducing bioaccessibility to the level of the standard conditions (Fig. 2B). We can only speculate for the reasons. It is possible that a higher amount of protein, perhaps in conjunction with a less complete digestion, resulted in liberating large peptides at the o/w interface, which may obstruct the displacement of WPI from lipid droplet surfaces and/or hindering digestive enzymes to adsorb to the droplet surfaces as reported previously (Qiu, Zhao, Decker, \& McClements, 2015). In general, the negative effects of WPI were more pronounced (reducing bioaccessibility by up to $70 \%$ ) and consistent compared to the positive effects, and were observed especially at conditions reflecting incomplete lipid digestion (low amount of bile and/or pancreatin, or high content of oil).

It is proposed, as supported by the observed smaller lipid droplet size with higher protein addition (Fig. 4), that emulsion stability is influenced, in addition to the presence of emulsifiers, by the oil 
droplet size, and by the formation of a viscoelastic film at the oil droplet interface, formed by peptides liberated during the GI digestion of whey proteins (Schröder, Berton-Carabin, Venema, \& Cornacchia, 2017). In general, it is accepted that smaller lipid droplet size enhances lipid digestion and thus carotenoid micellization (Salvia-Trujillo, Qian, Martin-Belloso, \& McClements, 2013), though in this study, we were unable to measure the effect of proteins on lipid digestion due to the over-layering effect of protein buffering capacity and/or hydrolysis.

Also, it was also shown earlier that the generated peptides strongly affected the stability of the $\mathrm{o} / \mathrm{W}$ emulsions during the gastric phase, dictating the resulting size of lipid droplets (Malaki Nik, Wright, \& Corredig, 2011). Thereupon, WPI-coated droplets, at least during earlier stages of digestion, may hinder the access of pancreatic lipase (and pancreatic co-lipase) to the droplet surface, especially at low bile salt concentration, due to the large and/or compact peptide film adsorbed to the lipid droplet surfaces (Qiu, Zhao, Decker, \& McClements, 2015). In our study, this effect was corroborated by lower amounts of pepsin (Fig. 3A), and perhaps a less complete protein digestion, though this could not be differentiated in the present SDS-page (supplementary fig. 5). However, protein digestion following gastric phase was found to be incomplete, with remaining bands of $\alpha$-lactalbumin and/or $\beta$-lactoglobulin, which may have restricted the subsequent adsorption of lipase required for lipid digestion. This could have resulted in the observed decrease in $\beta$ carotene bioaccessibility (by $40 \%$ ), which was not observed with regular or elevated amounts of pepsin (2000 or $4000 \mathrm{U} / \mathrm{mL}$, respectively).

Likewise in line, reducing the amount of pancreatin (Fig. 2B) or doubling the amount of oil (Fig. 1B) resulted in negative effects on $\beta$-carotene bioaccessibility, by up to $50 \%$. Pancreatin contains lipase, allowing for fat hydrolysis, and either doubling the amount of oil, or halving the amount of pancreatin could cause a relative lack of lipolytic enzymes, thereby promoting incomplete droplet processing, flocculation and coalescence (Qiu, Zhao, Decker, \& McClements, 2015). The addition 
of WPI further impeded the bioaccessibility in a dose-dependent manner, decreasing $\beta$-carotene bioaccessibility by half with a higher dose of WPI, compared to the control conditions.

Finally, halving the amount of bile (Fig. 3B) resulted in one of the most drastic negative effects on $\beta$-carotene bioaccessibility, with the addition of WPI reducing bioaccessibility of $\beta$-carotene to one third (Fig. 3B). The results obtained by Nik et al. showed that WPI undergoes further displacement from lipid droplet surfaces in the presence of other surface-active compounds, such as bile salts during the intestinal phase, offering finally access to lipolytic enzymes (Malaki Nik, Wright, \& Corredig, 2011). In their study, this induced a higher degree of lipolysis and led to the formation of a smaller lipid droplets. This suggests that, in addition to proteolytic enzymes and peristalsis movements, the presence of bile at the interfacial composition of the original emulsion plays a major role in determining the extent of lipolysis.

The additional physico-chemical properties investigated following GI digestion under standard conditions yielded additional insights regarding potential effects of WPI on digestive processes and carotenoid bioaccessibility. Firstly, the addition of proteins did not have a marked effect on the macro-viscosity or surface tension of the digesta, precluding that changes in these parameters effected bioaccessibility. This is further corroborated by the small changes in sheer-forces, and in line with a rather complete hydrolysis of added proteins following GI digestion to smaller, non SDS-PAGE detectable fragments, under all digestive conditions (suppl. Fig. 5). In the future, it would be interesting to follow the fate of smaller protein fragments, e.g. by LC-MS-MS, which was not carried out in the present study. However and secondly, protein addition, via their emulsifying properties, reduced lipid droplet size after digestion, and also resulted in lower mixed micelle size, which may have contributed to the positive effect on carotenoid bioaccessibility. It is unclear why the absolute zeta-potential was somewhat decreased with higher protein addition, suggesting a less stable emulsion, though effects could have contributed to the mixed effects encountered. 
In summary, the addition of WPI during simulated GI digestion influenced the bioaccessibility of $\beta$-carotene positively as well as negatively, depending on the digestion conditions. The results obtained in this study are in line with previous findings regarding the ability of WPI to adsorb to lipid droplet surfaces and playing a major role in stabilizing o/w emulsions, dictating the fate of lipophilic compounds. In this study, the ability of WPI to improve $\beta$-carotene bioaccessibility was somewhat limited (around 20\%), and found when applying a higher peristalsis energy (rather more suggestive of a healthy situation), or when reducing dietary lipids. The negative effects resulted following halving the amount of enzymes (pancreatin and pepsin) or doubling the amount of oil, and halving the amount of bile, decreasing the bioaccessibility of $\beta$-carotene up to one third after the addition of WPI. These results suggest that WPI and possibly other proteins may modulate carotenoid bioaccessibility, likely via their interaction during the processing of lipid droplets into mixed micelles during digestion as suggested by the altered droplet sizes found. When hypothetically transferring results to humans, a negative influence of WPI on $\beta$-carotene may be expected when digestion is less complete as characterized by lower enzyme secretion, while under rather normal and healthy conditions no negative effects may occur. Finally, a potential influence of WPI on other carotenoids (such as xanthophylls), and/or the influence of other proteins on $\beta$ carotene remains to be shown, as well as the possible influence of the food-matrix on proteincarotenoid interactions, and importantly, a confirmation of such in vitro results by in vivo studies.

\section{Acknowledgements}

The authors are grateful for the support of the Fonds National de la Recherche Luxembourg (Grant No. C16/BM/11320230). The insights obtained from the EU-COST actions EUROCAROTEN (CA15136) and POSITIVE (FA 1403) are much appreciated. The authors thank Yvan Devaux, head of cardiovascular research unit, for placing CVRU facilities at our disposal. 
The help of Bernadette Leners during digestions, fatty acid titrations and SDS-page is much appreciated.

The authors declare that there are no conflicts of interest.

M.I. conducted the majority of the analyses and wrote the first version of the manuscript. T.B. designed the trials and aided in statistical evaluation and manuscript preparation. C.D. conducted a large number of digestion experiments. Y.L. participated in the design of the study and the final manuscript version. T.S. conducted viscosity measurements, G.D. performed surface tension and lipid titration experiments. C.D. and P.B. conducted the analyses of zeta potential and micelle size. 


\section{References}

Arunkumar, R., Calvo, C. M., Conrady, C. D., \& Bernstein, P. S. (2018). What do we know about the macular pigment in AMD: the past, the present, and the future. Eye (Lond), 32(5), 992-1004.

Biehler, E., \& Bohn, T. (2010). Methods for assessing aspects of carotenoid bioavailability. Current Nutrition \& Food Science, 6(1), 44-69.

Biehler, E., Hoffmann, L., Krause, E., \& Bohn, T. (2011). Divalent minerals decrease micellarization and uptake of carotenoids and digestion products into Caco-2 cells. Journal of Nutrition, 141(10), 17691776.

Bohn, T. (2008). Bioavailabilty of non-provitamin A carotenoids. Current Nutrition and Food Science, 4(4), 240-258.

Bohn, T., Desmarchelier, C., Dragsted, L. O., Nielsen, C. S., Stahl, W., Rühl, R., Keijer, J., \& Borel, P. (2017). Host-related factors explaining interindividual variability of carotenoid bioavailability and tissue concentrations in humans. Molecular Nutrition and Food Research, 61(6), in press.

Borel, P., Desmarchelier, C., Dumont, U., Halimi, C., Lairon, D., Page, D., Sebedio, J. L., Buisson, C., Buffiere, C., \& Remond, D. (2016). Dietary calcium impairs tomato lycopene bioavailability in healthy humans. British Journal of Nutrition, 116(12), 2091-2096.

Britton, G., Liaaen-Jensen, S., \& Pfander, H. (2004). Carotenoids Handbook (Eds), Compiled by A. Z. Mercadante and E. S. Egeland, Birkhauser Verlag, Basle, Switzerland, 2004. Free Radical Research, 38(8), 885-885.

Carbonaro, M., Maselli, P., \& Nucara, A. (2012). Relationship between digestibility and secondary structure of raw and thermally treated legume proteins: a Fourier transform infrared (FT-IR) spectroscopic study. Amino Acids, 43(2), 911-921.

Caris-Veyrat, C., Garcia, A. L., Reynaud, E., Lucas, R., Aydemir, G., \& Rühl, R. (2016). Lycopene-induced nuclear hormone receptor signalling in inflammation and lipid metabolism via still unknown endogenous apo-10'-lycopenoids. International Journal for Vitamimn and Nutrition Research, 86, 62-70.

Chatterton, D. E. W., Smithers, G., Roupas, P., \& Brodkorb, A. (2006). Bioactivity of $\beta$-lactoglobulin and $\alpha$ lactalbumin-Technological implications for processing. International Dairy Journal, 16(11), 12291240.

Corte-Real, J., Desmarchelier, C., Borel, P., Richling, E., Hoffmann, L., \& Bohn, T. (2018). Magnesium affects spinach carotenoid bioaccessibility in vitro depending on intestinal bile and pancreatic enzyme concentrations. Food Chemistry, 239, 751-759.

Corte-Real, J., Richling, E., Hoffmann, L., \& Bohn, T. (2014). Selective factors governing in vitro betacarotene bioaccessibility: negative influence of low filtration cutoffs and alterations by emulsifiers and food matrices. Nutrition Research, 34(12), 1101-1110.

Desmarchelier, C., \& Borel, P. (2017). Overview of carotenoid bioavailability determinants: From dietary factors to host genetic variations. Trends in Food Science \& Technology, 69, 270-280.

Edes, T. E., Walk, B. E., Thornton, W. H., Jr., \& Fritsche, K. L. (1991). Essential fatty acid sufficiency does not preclude fat-soluble-vitamin deficiency in short-bowel syndrome. American Journal of Clinical Nutrition, 53(2), 499-502.

Elliott, R. (2005). Mechanisms of genomic and non-genomic actions of carotenoids. Biochimica et Biophysica Acta (BBA) - Molecular Basis of Disease, 1740(2), 147-154. 
Granado-Lorencio, F., Simal-Anton, A., Blanco-Navarro, I., Gonzalez-Dominguez, T., \& Perez-Sacristan, B. (2011). Depletion of serum carotenoid and other fat-soluble vitamin concentrations following obesity surgery. Obesity Surgery, 21(10), 1605-1611.

Hautvast, J. G., Baya, C., Amorim Cruz, J. A., de Backer, G. G., Ducimetiere, P., Durnin, J. V., Faivre, J., Ghione, S., Gibney, M. J., Gustafsson, J. A., \& et al. (1989). Recommended dietary allowances for Europe. Lancet, 2(8673), 1220.

Huo, T., Ferruzzi, M. G., Schwartz, S. J., \& Failla, M. L. (2007). Impact of fatty acyl composition and quantity of triglycerides on bioaccessibility of dietary carotenoids. Journal of the Agricultural and Food Chemistry, 55(22), 8950-8957.

Kaulmann, A., \& Bohn, T. (2014). Carotenoids, inflammation, and oxidative stress--implications of cellular signaling pathways and relation to chronic disease prevention. Nutrition Research, 34(11), 907-929.

Kim, G.-N., Jang, H.-D., \& Kim, C.-I. (2007). Antioxidant capacity of caseinophosphopeptides prepared from sodium caseinate using Alcalase. Food Chemistry, 104(4), 1359-1365.

Krinsky, N. I. (2001). Carotenoids as antioxidants. Nutrition, 17(10), 815-817.

Malaki Nik, A., Wright, A. J., \& Corredig, M. (2011). Impact of interfacial composition on emulsion digestion and rate of lipid hydrolysis using different in vitro digestion models. Colloids Surf B Biointerfaces, 83(2), 321-330.

Mensi, A., Choiset, Y., Rabesona, H., Haertle, T., Borel, P., \& Chobert, J. M. (2013). Interactions of betalactoglobulin variants $A$ and $B$ with Vitamin A. Competitive binding of retinoids and carotenoids. Journal of the Agricultural and Food Chemistry, 61(17), 4114-4119.

Minekus, M., Alminger, M., Alvito, P., Ballance, S., Bohn, T., Bourlieu, C., Carriere, F., Boutrou, R., Corredig, M., Dupont, D., Dufour, C., Egger, L., Golding, M., Karakaya, S., Kirkhus, B., Le Feunteun, S., Lesmes, U., Macierzanka, A., Mackie, A., Marze, S., McClements, D. J., Menard, O., Recio, I., Santos, C. N., Singh, R. P., Vegarud, G. E., Wickham, M. S., Weitschies, W., \& Brodkorb, A. (2014). A standardised static in vitro digestion method suitable for food - an international consensus. Food and Function, 5(6), 1113-1124.

Mun, S., Kim, J., McClements, D. J., Kim, Y. R., \& Choi, Y. (2017). Fluorescence imaging of spatial location of lipids and proteins during digestion of protein-stabilized oil-in-water emulsions: A simulated gastrointestinal tract study. Food Chemistry, 219, 297-303.

O'Connell, O., Ryan, L., O'Sullivan, L., Aherne-Bruce, S. A., \& O'Brien, N. M. (2008). Carotenoid micellarization varies greatly between individual and mixed vegetables with or without the addition of fat or fiber. International Journal for Vitamin and Nutrition Research, 78(4-5), 238-246.

Permprasert, J., \& Devahastin, S. (2005). Evaluation of the effects of some additives and pH on surface tension of aqueous solutions using a drop-weight method. Journal of Food Engineering, 70(2), 219226.

Pilbrow, J., Garama, D., \& Carne, A. (2012). Carotenoid-binding proteins; accessories to carotenoid function. Acta Biochimica Polonica, 59(1), 163-165.

Qiu, C., Zhao, M., Decker, E. A., \& McClements, D. J. (2015). Influence of protein type on oxidation and digestibility of fish oil-in-water emulsions: gliadin, caseinate, and whey protein. Food Chemistry, 175, 249-257.

Rao, A. V., \& Rao, L. G. (2007). Carotenoids and human health. Pharmacological Research, 55(3), 207-216.

Reboul, E., Richelle, M., Perrot, E., Desmoulins-Malezet, C., Pirisi, V., \& Borel, P. (2006). Bioaccessibility of carotenoids and vitamin $\mathrm{E}$ from their main dietary sources. Journal of the Agricultural and Food Chemistry, 54(23), 8749-8755. 
Salvia-Trujillo, L., Qian, C., Martin-Belloso, O., \& McClements, D. J. (2013). Influence of particle size on lipid digestion and beta-carotene bioaccessibility in emulsions and nanoemulsions. Food Chemistry, 141(2), 1472-1480.

Schröder, A., Berton-Carabin, C., Venema, P., \& Cornacchia, L. (2017). Interfacial properties of whey protein and whey protein hydrolysates and their influence on $\mathrm{O} / \mathrm{W}$ emulsion stability. Food Hydrocolloids, $73,129-140$.

Sharif, H. R., Williams, P. A., Sharif, M. K., Abbas, S., Majeed, H., Masamba, K. G., Safdar, W., \& Zhong, F. (2017). Current progress in the utilization of native and modified legume proteins as emulsifiers and encapsulants - A review. Food Hydrocolloids, 76, 2-16.

Sharoni, Y., Linnewiel-Hermoni, K., Khanin, M., Salman, H., Veprik, A., Danilenko, M., \& Levy, J. (2011). Carotenoids and apocarotenoids in cellular signaling related to cancer: A review. Molecular Nutrition and Food Research, 56, 259-269.

Sluijs, I., Cadier, E., Beulens, J. W. J., van der A, D. L., Spijkerman, A. M. W., \& van der Schouw, Y. T. (2015). Dietary intake of carotenoids and risk of type 2 diabetes. Nutrition, Metabolism and Cardiovascular Diseases, 25(4), 376-381.

Soukoulis, C., \& Bohn, T. (2018). A comprehensive overview on the micro- and nano-technological encapsulation advances for enhancing the chemical stability and bioavailability of carotenoids. Critical Reviews in Food Science and Nutrition, 58, 1-36.

van der Ven, C., Gruppen, H., de Bont, D. B. A., \& Voragen, A. G. J. (2001). Emulsion Properties of Casein and Whey Protein Hydrolysates and the Relation with Other Hydrolysate Characteristics. Journal of Agricultural and Food Chemistry, 49(10), 5005-5012.

Yi, J., Li, Y., Zhong, F., \& Yokoyama, W. (2014). The physicochemical stability and in vitro bioaccessibility of beta-carotene in oil-in-water sodium caseinate emulsions. Food Hydrocolloids, 35, 19-27. 


\section{Tables}

Table 1. Overview of digestion conditions studied in dependence of various concentrations of whey protein isolate (WPI).

\section{Aspect of digestion Condition Parameters chosen $\$$}

\begin{tabular}{|c|c|c|}
\hline \multirow[t]{2}{*}{ Matrix } & Amount of WPI & $0 \mathrm{mg} / \mathrm{mL}, 7.5 \mathrm{mg} / \mathrm{mL}, 15 \mathrm{mg} / \mathrm{mL}$ \\
\hline & Amount of oil & $3 \mathrm{~g} / \mathrm{L}, 6 \mathrm{~g} / \mathrm{L}^{*}, 12 \mathrm{~g} / \mathrm{L}$ \\
\hline \multirow[t]{3}{*}{ Gastric } & Peristalsis speed & $75 \mathrm{rpm} *, 100 \mathrm{rpm}$ \\
\hline & Gastric duration & $1 \mathrm{~h}, 2 \mathrm{~h}^{*}$ \\
\hline & Amount of pepsin & $1000 \mathrm{U} / \mathrm{mL}, 2000 \mathrm{U} / \mathrm{mL}^{*}, 4000 \mathrm{U} / \mathrm{mL}$ \\
\hline \multirow[t]{3}{*}{ Small intestine } & Peristalsis speed & $75 \mathrm{rpm} *, 100 \mathrm{rpm}$ \\
\hline & Amount of bile & $3.4 \mathrm{mg} / \mathrm{mL}^{\&}, 6.8 \mathrm{mg} / \mathrm{mL}^{*}, 13.6 \mathrm{mg} / \mathrm{mL}$ \\
\hline & Amount of pancreatin & $100 \mathrm{U} / \mathrm{mL}^{\&}, 200 \mathrm{U} / \mathrm{mL}^{*}, 400 \mathrm{U} / \mathrm{mL}$ \\
\hline
\end{tabular}


Table 2. Average bioaccessibility $(\%)^{1}$ of pure $\beta$-carotene digested with whey protein isolate (WPI) at varying concentrations ${ }^{2}$. Values represent mean \pm SD of $n=4$ and $\mathrm{N} \geq 2$ (sets repeated at different days). Means without a common superscript differ significantly, $P<0.05$.

\section{Bioaccessibility (\%)}

WPI (\% RDA)

\begin{tabular}{|c|c|c|c|}
\hline Condition & 0 & 25 & 50 \\
\hline \multicolumn{4}{|l|}{ Oil } \\
\hline $3 \mathrm{~g} / \mathrm{L}^{\mathrm{I}}$ & $21.4 \pm 2.2^{\mathrm{A}}$ & $25.6 \pm 0.8^{\mathrm{B}}$ & $22.7 \pm 0.9^{\mathrm{A}}$ \\
\hline $6 \mathrm{~g} / \mathrm{L}^{\mathrm{I}}$ & $24.8 \pm 2.5^{\mathrm{A}}$ & $24.1 \pm 3.3^{\mathrm{A}}$ & $30.6 \pm 2.8^{\mathrm{A}}$ \\
\hline $12 \mathrm{~g} / \mathrm{L}^{\text {II }}$ & $20.7 \pm 1.2^{\mathrm{A}}$ & $16.8 \pm 1.2^{\mathrm{B}}$ & $13.5 \pm 0.8^{C}$ \\
\hline \multicolumn{4}{|c|}{ Peristalsis energy } \\
\hline $75 \mathrm{rpm}^{\mathrm{I}}$ & $24.8 \pm 2.5^{\mathrm{A}}$ & $24.1 \pm 3.3^{\mathrm{A}}$ & $30.6 \pm 2.8^{\mathrm{A}}$ \\
\hline $100 \mathrm{rpm}^{\text {II }}$ & $50.8 \pm 2.6^{\mathrm{A}}$ & $58.7 \pm 1.3^{\mathrm{B}}$ & $49.3 \pm 2.5^{\mathrm{A}}$ \\
\hline \multicolumn{4}{|c|}{ Gastric duration } \\
\hline \multicolumn{4}{|c|}{$\overline{\text { At } 75 \text { rpm }}$} \\
\hline $\mathbf{1 h}^{\mathrm{I}}$ & $18.6 \pm 1.1^{\mathrm{A}, \mathrm{B}}$ & $17.4 \pm 1.9^{\mathrm{A}}$ & $19.2 \pm 1.5^{\mathrm{B}}$ \\
\hline $2 \mathbf{h}^{\text {II }}$ & $24.8 \pm 2.5^{\mathrm{A}}$ & $24.1 \pm 3.3^{\mathrm{A}}$ & $30.6 \pm 2.8^{\mathrm{A}}$ \\
\hline \multicolumn{4}{|l|}{ At 100 rpm } \\
\hline $1 h^{\text {III }}$ & $46.1 \pm 1.2^{\mathrm{A}}$ & $54.6 \pm 1.6^{\mathrm{B}}$ & $50.7 \pm 1.2^{\mathrm{C}}$ \\
\hline $2 h^{\text {IV }}$ & $50.8 \pm 2.6^{\mathrm{A}}$ & $58.7 \pm 1.3^{\mathrm{B}}$ & $49.3 \pm 2.5^{\mathrm{A}}$ \\
\hline \multicolumn{4}{|l|}{ Pepsin } \\
\hline $1000 \mathrm{U} / \mathrm{mL}^{\mathrm{I}}$ & $26.1 \pm 2.1^{\mathrm{A}}$ & $15.7 \pm 1.7^{\mathrm{B}}$ & $19.9 \pm 1.1^{\mathrm{C}}$ \\
\hline $2000 \mathrm{U} / \mathrm{mL}^{\mathrm{II}}$ & $24.8 \pm 2.5^{\mathrm{A}}$ & $24.1 \pm 3.3^{\mathrm{A}}$ & $30.6 \pm 2.8^{\mathrm{A}}$ \\
\hline $4000 \mathrm{U} / \mathrm{mL}^{\mathrm{II}}$ & $4 \pm 0.9^{\mathrm{A}}$ & $24.9 \pm 1.9^{\mathrm{A}}$ & $24.7 \pm 1.2^{\mathrm{A}}$ \\
\hline \multicolumn{4}{|l|}{ Pancreatin } \\
\hline At 75 rpm & & & \\
\hline $100 \mathrm{U} / \mathbf{m L}^{\prime}$ & $24.7 \pm 1.6^{\mathrm{A}}$ & $18.4 \pm 0.7^{\mathrm{B}}$ & $12.7 \pm 1.9^{\mathrm{C}}$ \\
\hline $200 \mathrm{U} / \mathrm{mL}^{\mathrm{II}}$ & $24.8 \pm 2.5^{\mathrm{A}}$ & $24.1 \pm 3.3^{\mathrm{A}}$ & $30.6 \pm 2.8^{\mathrm{A}}$ \\
\hline $400 \mathrm{U} / \mathrm{mL}^{\mathrm{III}}$ & $34.7 \pm 1.6^{\mathrm{A}}$ & $28.8 \pm 2.3^{\mathrm{B}}$ & $33.3 \pm 2.2^{\mathrm{A}}$ \\
\hline \multicolumn{4}{|l|}{ At 100 rpm } \\
\hline $100 \mathrm{U} / \mathrm{mL}^{\mathrm{IV}}$ & $45.5 \pm 3.6^{\mathrm{A}}$ & $51.9 \pm 0.7^{\mathrm{B}}$ & $40.8 \pm 1.4^{\mathrm{C}}$ \\
\hline $200 \mathrm{U} / \mathrm{mL}^{\mathrm{v}}$ & $50.8 \pm 2.6^{\mathrm{A}}$ & $58.7 \pm 1.3^{\mathrm{B}}$ & $49.3 \pm 2.5^{\mathrm{A}}$ \\
\hline $400 \mathrm{U} / \mathrm{mL}^{\mathrm{VI}}$ & $67.7 \pm 3.7^{\mathrm{A}}$ & $65.9 \pm 3.9^{\mathrm{A}}$ & $58.2 \pm 3.9^{\mathrm{B}}$ \\
\hline \multicolumn{4}{|l|}{ Bile extract } \\
\hline $3.4 \mathrm{mg} / \mathrm{mL}^{\mathrm{I}}$ & $21.1 \pm 0.9^{\mathrm{A}}$ & $10.0 \pm 0.7^{\mathrm{B}}$ & $7.5 \pm 0.9^{C}$ \\
\hline $6.8 \mathrm{mg} / \mathrm{mL}^{\mathrm{II}}$ & $24.8 \pm 2.5^{\mathrm{A}}$ & $24.1 \pm 3.3^{\mathrm{A}}$ & $30.6 \pm 2.8^{\mathrm{A}}$ \\
\hline $13.6 \mathrm{mg} / \mathrm{mL}^{\text {II }}$ & $25.5 \pm 0.7^{\mathrm{A}}$ & $26.5 \pm 1.1^{\mathrm{A}}$ & $22.6 \pm 0.7^{\mathrm{B}}$ \\
\hline
\end{tabular}

RDA: recommended dietary allowance. ${ }^{1}$ Bioaccessibility is expressed as the percentage of $\beta$ carotene recovered at the end of the in vitro GI digestion, compared to the amount added at the beginning of digestion. ${ }^{2}$ Concentrations given in final digestion stage (small intestine) are 0,25 and $50 \%$ based-RDA. 


\section{Figure Headings}

Fig. 1. Influence of whey protein isolate (WPI) (A), and oil, co-digested with WPI (B) on $\beta$ carotene bioaccessibility at $75 \mathrm{rpm}$ water bath shaking speed. $\beta$-Carotene was digested either in the presence of WPI at different amounts $(0,187$ and $375 \mathrm{mg}$ per final $25 \mathrm{~mL}$ digesta volume, representing 0,25 and $50 \%$ of protein recommended dietary allowance (RDA)), or in the presence of different volumes of oil (75, 150 and $300 \mu \mathrm{L}$ per final $25 \mathrm{~mL}$ digesta), at various amounts of WPI $(0,25$ and $50 \%$ of RDA) at $75 \mathrm{rpm}$. Bioaccessibility is expressed as the percentage of $\beta$-carotene recovered from the aqueous micellar fraction at the end of the in vitro GI digestion, compared to the amount of $\beta$-carotene added at the beginning of digestion. Values represent means \pm SD of $n=4$ and $\mathrm{N} \geq 2$ (sets repeated at different days). Labeled means without a common superscript (alphabetic letters or roman numbers) differ significantly, $P<0.05$.

Fig. 2. A) Influence of peristalsis energy and gastric phase duration on $\beta$-carotene bioaccessibility and the effect of additional co-digested whey protein isolate (WPI). B) Influence of pancreatin concentration on $\beta$-carotene bioaccessibility and the effect of additional co-digested whey protein isolate (WPI) at 75 (left panel) and $100 \mathrm{rpm}$ (right panel) water bath shaking speed. $\beta$ Carotene was digested in the presence of different amounts of pancreatin representing 50, 100 and $200 \mathrm{U} / \mathrm{mL}$ digesta, expressed as protease activity, in the presence of various amounts of WPI $(0$, 187 and $375 \mathrm{mg}$ per final $25 \mathrm{~mL}$ digesta volume, representing 0,25 and $50 \%$ of recommended dietary allowance (RDA)) at $75 \mathrm{rpm}$ and $100 \mathrm{rpm}$. Bioaccessibility is expressed as explained in Fig. 1 heading. Values represent means $\pm \mathrm{SD}$ of $n=4$ and $\mathrm{N} \geq 2$ (sets repeated at different days). Labeled means without a common superscript (alphabetic letters or roman numbers) differ significantly, $P<0.05$. 
Fig. 3. Influence of pepsin (A), and bile extract concentration (B) on $\beta$-carotene bioaccessibility and the effect of additional co-digested whey protein isolate (WPI) at $75 \mathrm{rpm}$ water bath shaking speed. $\beta$-Carotene was digested either in the presence of pepsin at different concentrations (1000, 2000 and $4000 \mathrm{U} / \mathrm{mL}$ digesta), or in the presence of different concentrations of bile extract $(3.4,6.8$ and $13.6 \mathrm{mg} / \mathrm{mL}$ per final $25 \mathrm{~mL}$ digesta); as well as in the presence of various amounts of WPI $(0$, 187 and $375 \mathrm{mg}$ per final $25 \mathrm{~mL}$ digesta volume, representing 0,25 and $50 \%$ of protein recommended dietary allowance (RDA)) at $75 \mathrm{rpm}$. Bioaccessibility is expressed as explained in fig. 1 heading. Values represent means \pm SD of $n=4$, and $\mathrm{N} \geq 1$ for the experiment with bile extract and $\mathrm{N} \geq 2$ for the experiment with pepsin (sets repeated at different days). Labeled means without a common superscript (alphabetic letters or roman numbers) differ significantly, $P<0.05$.

Fig. 4. Distribution of lipid droplets in the presence and absence of whey protein isolate (WPI), before and after gastro-intestinal digestion (panel A) and colocation of lipids and proteins of samples representing a protein concentration equivalent to $25 \%$ of the recommended dietary allowance (RDA) in the digesta (panel B). The white bar indicates $10 \mu \mathrm{m}$. Confocal imaging of emulsion structures was carried out at room temperature with a confocal laser scanning microscope (Zeiss LSM 880, Airyscam SR, Jena, Germany), using a 63x objective. The fluorescent dyes were excited by an Argon laser $(488 \mathrm{~nm})$ and the emitted light was collected at $522 \mathrm{~nm}$ for protein (green) and $635 \mathrm{~nm}$ for the fat phase (red). C) optical images of the samples following gastrointestinal digestion. 


\section{Highlights}

- Whey protein isolate modulates $\beta$-carotene bioaccessibility depending on digestive conditions.

- Reduced $\beta$-carotene bioaccessibility was pronounced with impaired lipid digestion.

- Strong positive influence of simulated peristalsis on $\beta$-carotene bioaccessibility. 
Figures

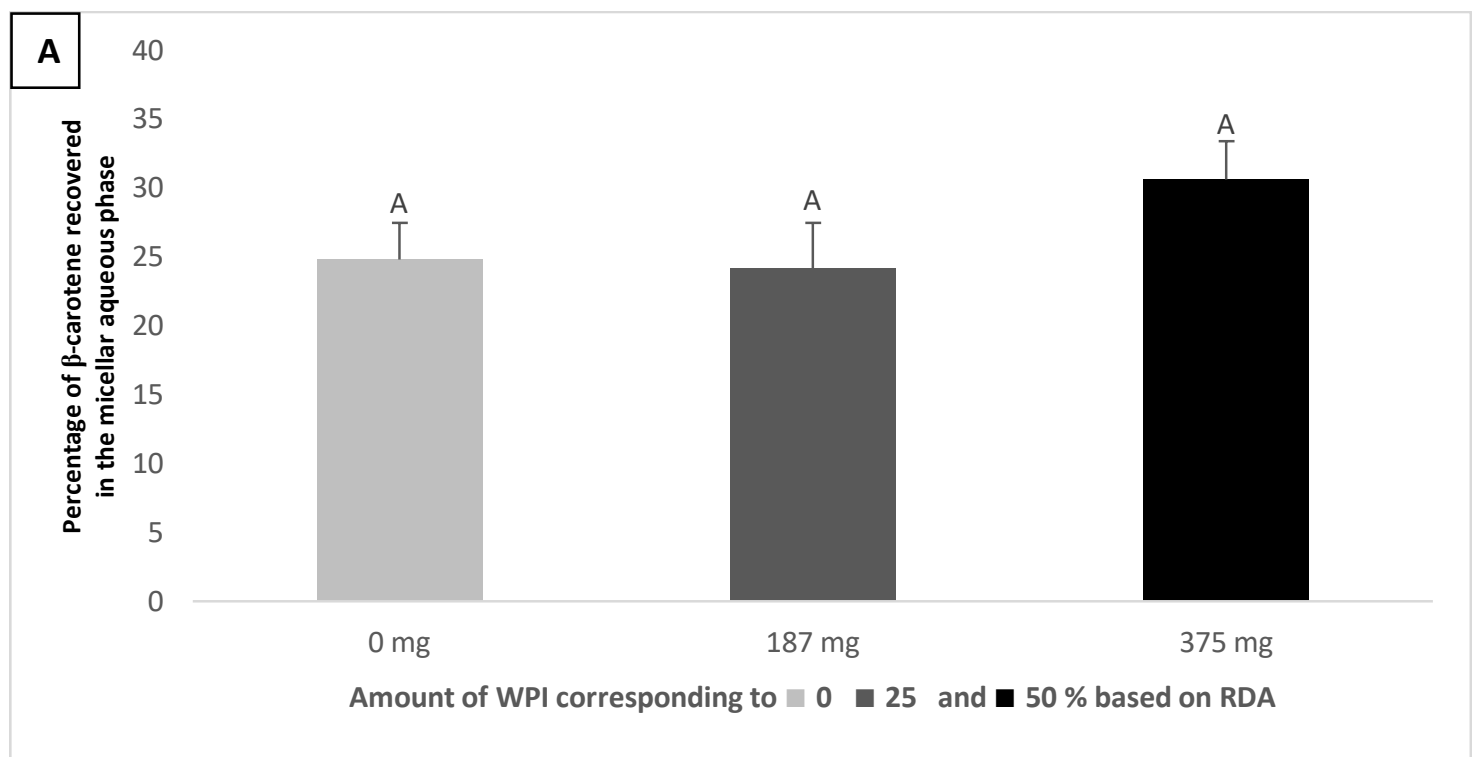

2

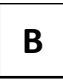

3

B
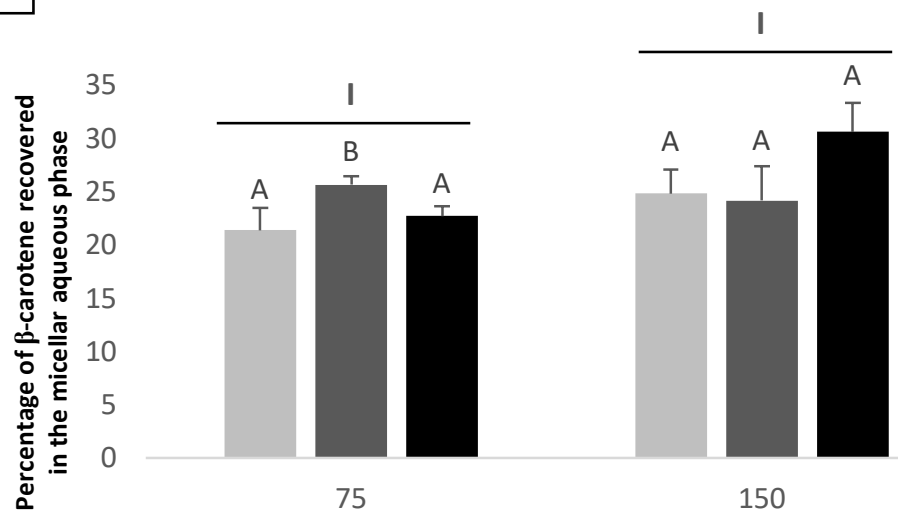

$\begin{array}{ll}\text { ஸ } & 30 \\ \frac{\pi}{0} & \end{array}$

ก

党

它 15

离 10

E 5

吕 0

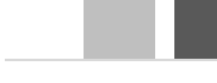

75

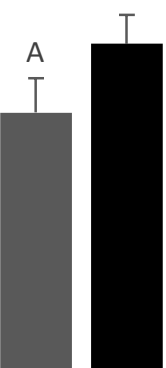

150

Amount of oil $(\mu \mathrm{L})$

$0 \square 25 \square 50 \%$ of WPI based on RDA

Figure 1

8

9

10

11

12 

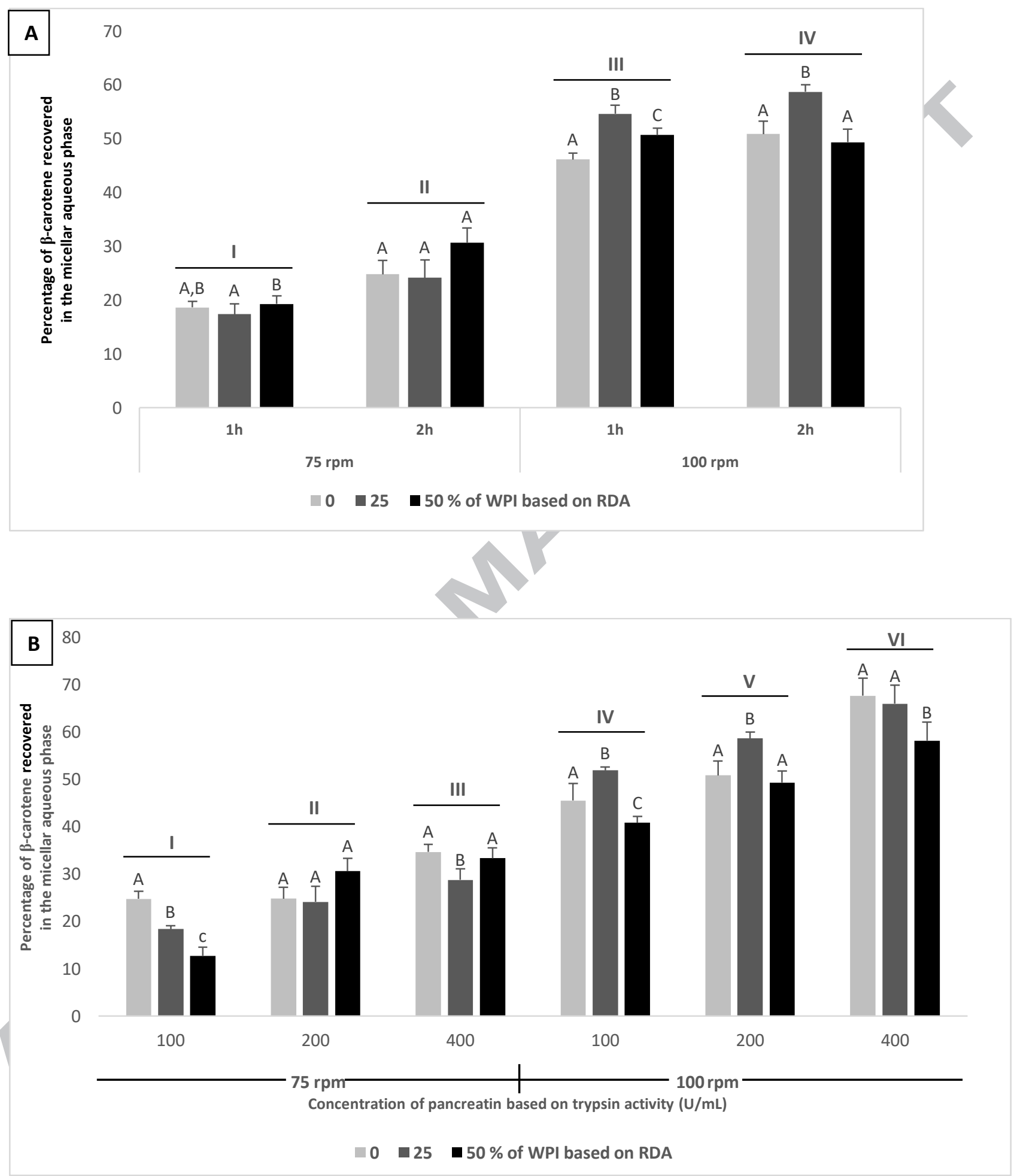

Figure 2 


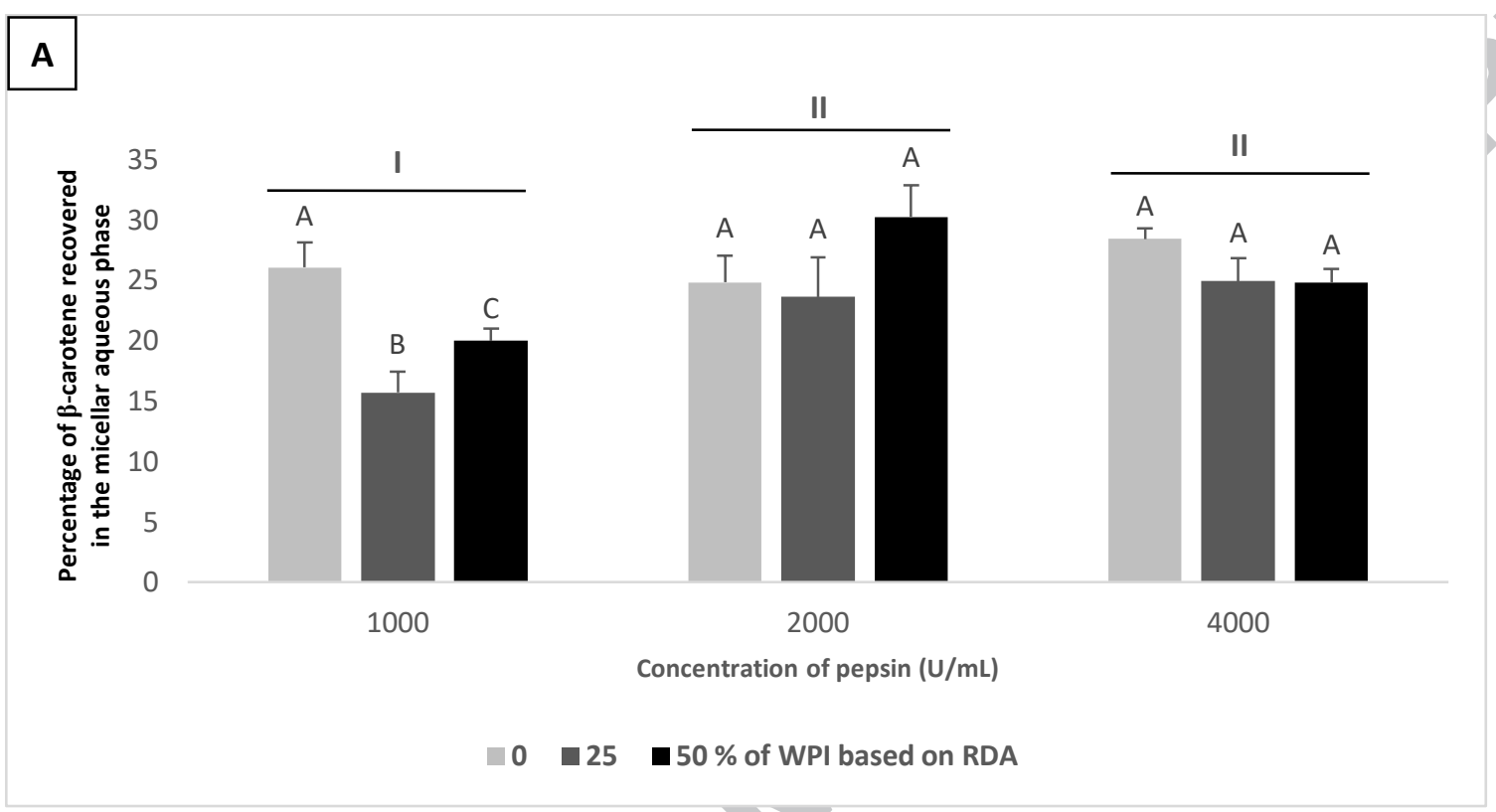

\section{B}

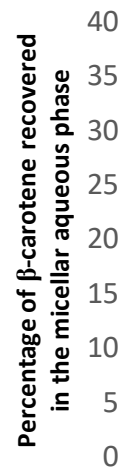

II

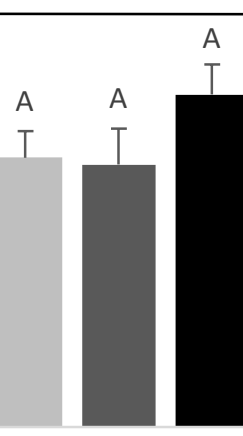

6.8

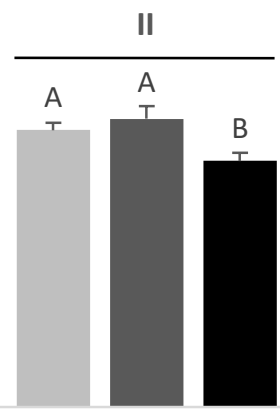

3.4

Amount of bile $(\mathrm{mg} / \mathrm{mL})$

13.6

$\square-25-50 \%$ of WPI based on RDA

Figure 3

30 


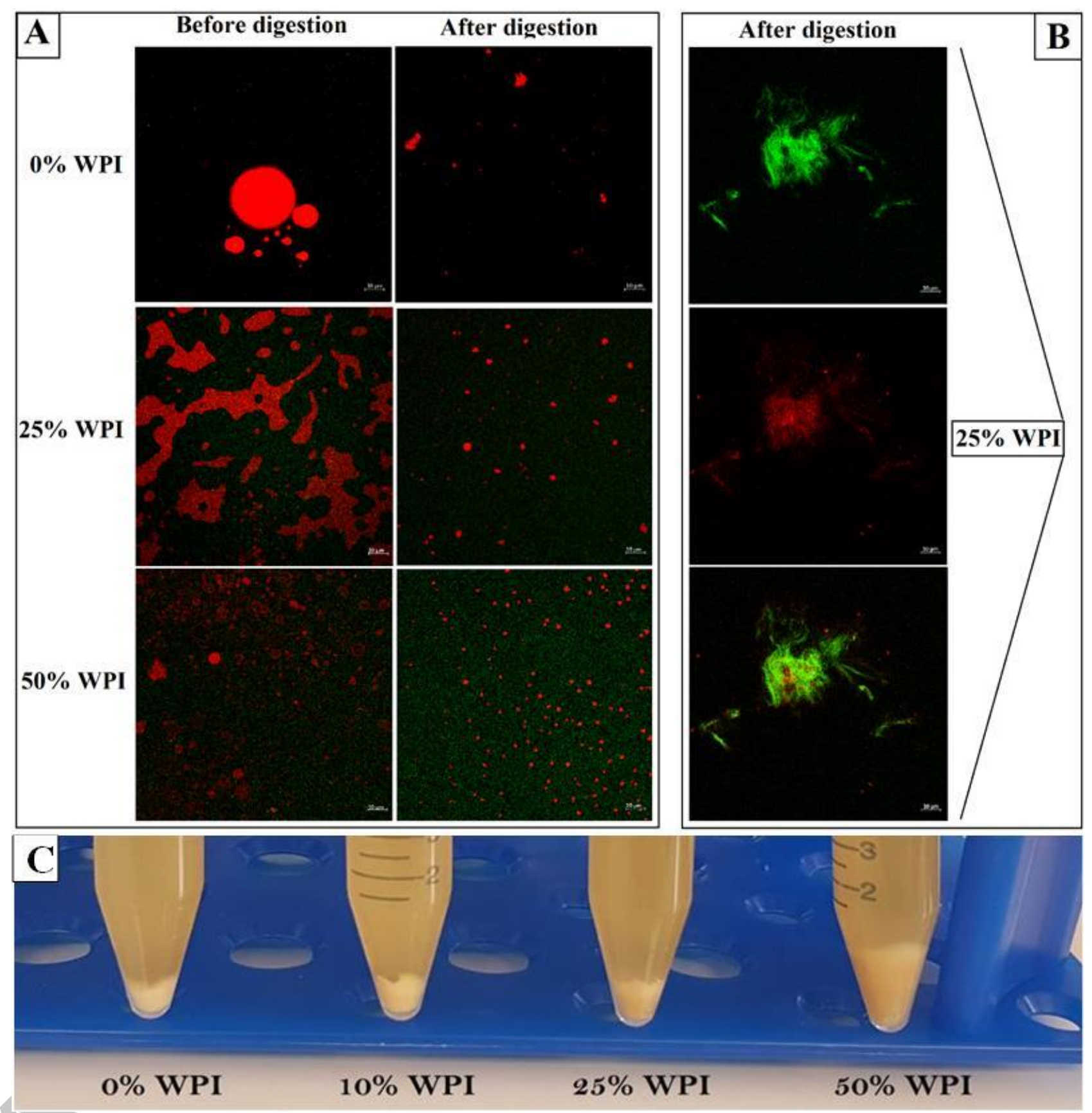

Figure 4 